\title{
A Journey to Cherish; How Transformational Leadership Affects Project Success through Team Performance
}

Hina Saleem ${ }^{1}$,IBIT, University of the Punjab, Email: hsaleem@ibitpu.edu.pk

Ali Sajid ${ }^{2}$,The University of Lahore. Email:ali.sajid@1sps.uol.edu.pk

Rashid Aftab ${ }^{\mathbf{3}}$,Riphah International University, Email: rashid.aftab@riphah.edu.pk

Zeeshan Malik ${ }^{4}$,The University of Lahore,Email: zeeshanmalik911@gmail.com

\begin{abstract}
Purpose: The study aims to explain the role of transformational leadership style in mediating team performance and its affect on project success.Approach/Methodology/Design: The method of determining the sample used is random sampling. The study population is construction companies in Pakistan. The sample used was a size of 230subordinates as respondents. Data collection is done through survey by distributing questionnaires offline that have been tested for validity and reliability. The data analysis technique used is the SEM-PLS Analysis.Findings: The results showed that transformational leadership variable positively and significantly affects project success.Transformational leadership has a positive relationship with team performance and team performance also has a positive relation with project success. This study also proves the direct and indirect affect of transformational leadership on project success.Practical Implication: Therefore, transformational leadership provides a clear understanding to improve rate of project success and team performance.Originality/Value:Increasing team performance strategy can significantly mediate the affect of transformational leadership on project success in construction sector of Pakistan.
\end{abstract}

Keywords:

Transformational leadership, team performance, project success

Article Received: 18 October 2020, Revised: 3 November 2020, Accepted: 24 December 2020

\section{Introduction}

In project management commonly success criteria is traditional which is in reality very practical in itself. Sometimes the success of the project relates with the other factors as well(Sebestyen, 2017). One of the success factor that is identified is the leadership style; with specially a positive effect of transformational leadership (Ahmed, 2017).In the organizations impressive leadership found as critical success factor and withthis effective leadership style project performance can be improved. Hence, unlike most project management previous studies on project success factors, studiesobserved the significance of leader of projects; about style and competence of leadership(Turner, 2005). Thus, leadership in the projects certainly needs much more attention both in terms of theory development and practical work, as it is a progressively important and widespread phenomenon in the overall budget(Packendorff, 2009).
The researchers discussed the number of investigations into the connection between project leader capabilities and project success. Communication, commitment and leadership appear as the three most relevant aspects in the success of projects (Alvarenga et al., 2018). Furthermore, some project leaders develop particular leadership behaviors in an attempt to increase the project performance(Braun, Peus, Weisweiler, \& Frey, 2013). Hence, leadership capabilities directly connected with measures of project success. Mainly, capabilities of project leader in handling limited resources with well planning have a significant relation with the most of success measures (Müller, Turner, Mu, \& Turner, 2012).

Project leader has very import role in improving project performance and expected to take part in the continuous improvement in project-based organizations(Sundqvist, 2019). In the 
organizations team leaders with great multi range cultural varieties foster innovative goals due to which team communication get improvedand reveal consistent results with respect to team innovation (Lisak et al., 2020).Teamshaving leading capabilities bringsvarious changes, such as itcreates supportive environment among team members having trust, coordination in the achievement of individual goals, supervising resources in better way, and organized transfer of informationfor task completion (Zaccaro, Rittman, \& Marks, 2001). Members of team should have positive traits such as communication skills, commitment with each other andgood response to make project efficient and successful. For practical completion of the project it is necessary teams possess key attributes (Oke, Olatunji, Awodele, \& Akinola, 2016).Appreciation of a leader on team members' commitmentduring project is a great way of increasing team performance. Team leader's encouragement is one of several factors that help in developing project commitment between team members and this encouragement to team members' also creates insightto support organization's objectives for the project success(Ehrhardt et al., 2020).Formal and informal communication also has some effect on project success.(Wu, Liu, Zhao, \& Zuo, 2017) concluded that formal communicationacts positively with project success.While, informal communication acts negatively with project success. Hence, it is required to increase the formal communication during the execution of projects among various project teams $(\mathrm{Wu}, \mathrm{Liu}$, Zhao, \& Zuo, 2017).

This study offers to investigate the leadership style; role of transformational leadership with project success. We propose team performance as mediating factor in the relation between two dependent and independent variables; transformational leadership and project success. Literature review of all variable, research design philosophy, supposition of hypothesis, methodology of research, analysis of findings, discussion, limitations and conclusion will be discussed to elaborate the investigation.

\section{Literature Review and Hypotheses}

\subsection{Transformational leadership}

Project managers having transformational leadership behavior are more expected to achieve success when dealing projects (Yang, Huang, \& $\mathrm{Wu}, 2011)$. Leadership behavior has a positive relationship to project success(Damayanti et al., 2019). In addition it was found that positive association among transformational leadership, operational efficiency and project (Ahmed, 2017). Project managers perform better when they follow transformational leadership style which leads in the achievement of project success (Maqbool, Sudong, Manzoor, \& Rashid, 2017).Project manager with his/her leadership skills, emotional and managerial skills impact on project success(Podgórska \& Pichlak, 2019).

Managerial leadership by inspiring and encouraging subordinates endeavors to attain better results than expected. That kind of leadership also helps subordinates to think new solutions of the problems with creative ideas, following group mission and goals instead of just personal interest which collectively leads to achieve higher project quality (Keller, 2017).Worldwide well known team leaders promote innovative goals because they are influenced with cultural diversity which also increases inclusion in team communication inclusion and team innovation (Lisak et al., 2020). Transformational leadership also supports team innovative performance and knowledge sharing (Chen, 2016). Transformational leadership contributed to team output effectiveness. Hence, managers should cooperate with team members during project while team member have responsibility to pay attention properly so overall performance get increased(Choi, Kim, Kang, \& City, 2017).

\subsection{Team Performance}


Project planning and project team buildingare very important to build up the foundation of any project. Most of the time successful projects are succeeded by an outstanding dedicated team (Michael, 2008). The quality of teamwork is a major factor in improving team performance. To optimize team performance quality of teamwork should be considered(Lindsjørn, Sjøberg, Dingsøyr, Bergersen, \& Dyb, 2016).Team performance increases by commitment based practices which includegivingvalue to team members and supporting environment for team members. These practices also helps team members to understand the goals, mission and strategies more clearly(Liu \& Wang, 2019). In the same way, task performance significantly related with team's trust. Team success is achieved by mutual support in team members in case of complex tasks. Teams that are emotionally intelligent promote trustworthy environment by establishing standards and normto increase task and team performance(Colquitt, Scott, \& LePine, 2007). Further, team goal commitment also provides support in increasing team performance in innovative tasks(Hoegl, 2006).

The communication awareness among team members makes better understanding during practical tasks and helpful both in term of effectiveness and efficiency. Effective communication during practical work further showed in the environment of highcommunication-awareness condition teams performance stick out by early and steady communication(Krancher, 2018). Team member effectiveness are positively related to the stability of the team and information processing (Woerkom, 2007). Effectiveness of team can be measured by both, the communication and the satisfaction dimensions. There is positive relation between his/her effectiveness in performing their day-to-day tasks and acknowledgment of a team member's talent(Sweis, Al Sharef, Jandali, Obeidat, \& Andrawes, 2018). Team effectiveness is also increased by team planning (Dechurch \& Haas, 2015).

\subsection{Project Success}

Researcher see project success more broadly as the multi-dimensional and networked nature of project success to achieve longer-term business objectives(Mu, 2014). So, project success based on budget, schedule, quality, client satisfaction,user's satisfaction, project personnel satisfaction, contracting partners' satisfaction, and stakeholders' satisfaction(Westerveld, 2003). Moreover, project success concerned with satisfying stakeholders' needs (Davis, 2014). In determining project success, relation of project ownerwith the key stakeholders is the most important by using the golden-triangle criteria (X. Wang, 2006).Hence, there are many factors of project success explained by (Radujkovi \& Sjekavica, 2017) project team's competence is one of them, which supports project manager. Soft skills of project managers like effective communication significantly contributed to the project success (Zuo, 2018).

\subsection{Research Model \& Hypothesis Development}

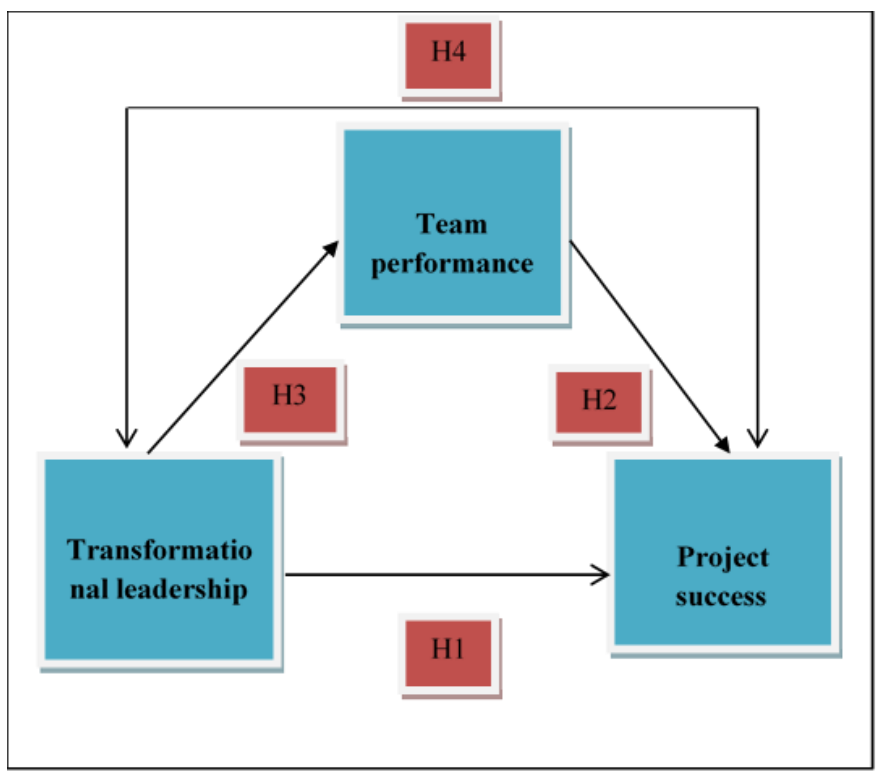

FIGURE 1: Research Model

H1: There is positive relationship of transformational leadership on project success.

Success of projects depends on leaders who are skilled in determining critical factors as well as 
leadership practices to accomplish project successfully(Cleveland \& Cleveland, 2020).Project manager's emotional, managerial skills and competencies help to achieve project success(Podgórska \& Pichlak, 2019). Transformational leadership ensures job satisfaction and enhances motivation level of followers. It also creates quality relationship between leader and follower. Performance outcomes of the followers increased due to motivation and affective organizational commitment (Ng, 2017).

H2: There is positive relationship of transformational leadership on team performance.

Transformational leadership is directly and indirectly related to team performance; relation is more strong in case of healthy team climate(Sun, $\mathrm{Xu}$, \& Shang, 2014). High skilled teams are formed when team is effectively motivated and interpersonal skills are taught and practiced(Cheruvelil et al., 2014). Four factors of transformational leadership (II,IM,IS,IC) createsconsistent way to increaseteam performance(Dionne et al., 2015).Performance at individual and team level increased in the presence of trust between team members and supervisors (Braun et al., 2013). Interpersonal skills play a critical role in establishing trust, such as knowledge sharing, motivation, leadership skills(Anantatmula, 2010).

H3: There is positive relationship of team performance on project success.

Emotional skills positively related with results of team task performance. Team emotional skills are very important in building team performance and individual team member performance(Troth, Jordan, Lawrence, \& Tse, 2020). All experts who work with team needs quality skill of empathy to build relationships between employees. This will also help to solve business problems more successfully. Therefore, subordinates learn new ways of working by getting involved in the problem-solving process and this will help in increase of productivity and performance (Sergey $\&$ Boris, 2020).

H4: There is positive mediating relationship of Team Performance between transformational leadership and project success

Project success is measured through transformational leadership (Aga, 2016) with mediating role of teambuilding and concluded that organizations need to encourageproject managers to adopt transformational leadership style. In addition, individual follower performance, team performance and organization performance positively related with transformational leadership(G. Wang, Oh, Courtright, \& Colbert, 2011).Personality traits of team members by creating suitable influences on member behaviors also affect team performance(Prewett, Goswami, \& Christiansen, 2016).Team psychology and learning behavior are positively related to transformational leadership(Rebelo, Dimas, Lourenço, Palácio, \& Rebelo, 2018).

\section{Research Methodology}

To measure impact of transformational leadership on project success we adopted a quantitative approach in this study.Stratified random sampling was adapted for this study and collect data randomly from different project related companies. The population consisted of all the project management participants in the construction industry in Multan. Two hundred and fifty questionnaires were distributed, out of which two hundred and thirty responses returned back, effective response rate was almost $90 \%$. To achieve accurate results with limited time horizon, cross-sectional method is adapted.

Questions are asked under 5 point Likert scalefrom strongly disagree to strongly agree. The measurements of dependent, independent and mediating variable are adapted. These previously used scales of the variables then adjusted according to our researchcontext; related to only construction companies in Pakistan. To measure 
transformational leadership used 7 items which are taken from (Carless, Wearing, \& Mann, 2000). To measure team performance used total 8 items from (Barrick, Stewart, Neubert, \& Mount, 1998). To measure project success used 9 items which are taken from $(\mathrm{Mu} \&$ Turner, 2005).Different tests were conducted to check the results. Descriptive statics, validity, normality, reliability, correlation, regression was examined. Two softwaresare used for getting results SPSS 23.0 and smart-PLS. Variance-based structural equation modelling (SEM) technique on SmartPLS tool is conducted for testing the hypotheses.

\section{Findings}

In the findings to measure and test the model Statistical Package for the Social Sciences (SPSS) version 23.0 and SmartPLS were used. To measure precise data internal consistency, normality, and validity of the variables were checked. Reliability can defined as the extent to which the produced results are consistent.Construct and composite reliability values above 0.70 are generally considered consistent(Hair, Sarstedt, Pieper, \& Ringle, 2012). Measured values ofCronbach's alpha for the considered variables showed resultsas TL (0.903), TP (0.839), and PS (0.842), and composite reliability as TL (0.881), TP (0.877), and PS (0.921)which showedthat overall internal consistency is excellent. Normality test is used for determining the measures have continuous data(Mishra, Pandey, \& Singh, 2019). Skewness and kurtosis to test data distribution type was used in this study.Data values between \pm 3 and \pm 10 considered to be normally distributed.(Hair et al., 2010) Our all values are between (-1.2 to 1.7) which are in acceptable range. In our study demographics showed that male participants were $53 \%$, majority has experience of $1-5$ years and 16 years education qualification.

According to deceptive analysis, mean values of all the variables above three which indicated the positive behaviour of respondents. Correlation coefficient between the variables TL and TP is and $(\mathrm{r}=.582)$ between TP and PS is $(\mathrm{r}=.595)$, greater than 0.3 which indicates moderate values respectively where $\mathrm{p}$ level is significant at 0.01 that is highest value of two-tailed significance. Regression analysis used to analyse the affect of one variable over another variable. Table 4 represents the good discriminant validitybecause average variance extracted (AVE) square root values is higher than the correlation coefficients. Furthermore, all AVE values and factors (outer) loadings are also above 0.5 . Model shows around $45 \%$ variance (R-square). Results shows the credibility of the model where significance level is $\mathrm{p}<0.000$ indicating $99 \%$ of confidence level.

\begin{tabular}{|c|c|c|c|c|c|}
\hline \multicolumn{7}{|c|}{ Table 1 } \\
\hline DESCRIPTIVE STATISTICS \\
\hline 1 & Variables & Skewness & Kurtosis & Mean & S.D \\
\hline 2 & TL & -1.060 & .442 & 3.85 & .52 \\
\hline 3 & TP & -1.120 & 1.765 & 3.87 & .53 \\
\hline
\end{tabular}

\begin{tabular}{|l|c|c|c|c|c|}
\hline \multicolumn{7}{|c|}{ Table 2 } \\
\hline \multicolumn{5}{|c|}{ RELIABILITY \& CORRELATION } \\
\hline Variables & Cronbach $\alpha$ & Composite & TL & TP & PS \\
\hline
\end{tabular}




\begin{tabular}{|c|c|c|c|c|c|}
\hline & & Relaibility & & & \\
\hline TL & .903 & .881 & $\mathbf{1}$ & & \\
\hline TP & .839 & .877 & .525 & $\mathbf{1}$ & \\
\hline PS & .842 & .921 & .512 & .533 & $\mathbf{1}$ \\
\hline
\end{tabular}

\begin{tabular}{|c|c|c|c|c|}
\hline \multicolumn{5}{|c|}{ Table 3 } \\
Validity \\
\hline Variables & AVE & & TP & TL \\
\cline { 3 - 5 } & & PS & & \\
\hline PS & 0.571 & 0.756 & 0.713 & 0.719 \\
\hline TP & 0.568 & 0.722 & 0.677 & Discriminant validity \\
\hline TL & 0.537 & 0.727 & & \\
\hline
\end{tabular}

\section{Table 4}

\section{REGRESSION ANALYSIS}

\begin{tabular}{|l|c|c|c|c|c|}
\hline Variables & B & S.E & T Statistics & P value & $\mathrm{R}^{2}$ \\
\hline TL -> PS & 0.440 & 0.069 & 6.537 & 0.000 & \\
\cline { 1 - 5 } TL -> TP & 0.677 & 0.035 & 11.547 & 0.000 & \multirow{2}{*}{0.459} \\
\cline { 1 - 5 } & & & & 0.000 & \\
\hline
\end{tabular}

$\beta$ is the standardized path coefficient

S.E stands for standard error

First path tested was from transformational leadership to project success is $(\beta=0.440, \mathrm{p}<$ 0.001 ) shows that transformational leadership has significant association with project success. Hence, hypothesis $\mathrm{H}_{1}$ thatwe proposed is accepted. Second path tested was from transformational leadership to team performance and the $(\beta=0.677$, $\mathrm{p}<0.001$ ) shows that transformational leadership has significant association with team performance. Hence, hypothesis $\mathrm{H}_{2}$ that proposed is accepted. Third path tested was from team performance to project success and the $(\beta=0.424, p<0.001)$ shows that team performance have positive impact with Project success. Hence, hypothesis $\mathrm{H}_{3}$ which proposed is accepted.

\begin{tabular}{|l|c|c|c|c|}
\hline \multicolumn{5}{|c|}{ Table 5 } \\
\hline \multicolumn{4}{|c|}{ MEDIATION ANALYSIS } \\
\hline $\begin{array}{l}\text { Indirect Path } \\
\text { PS }->\text { TP } \rightarrow\end{array}$ & B & S.E & T Statistics & P value \\
\hline
\end{tabular}

In indirect effect the mediating role of team performance among transformational leadership and project success is $(\beta=0.287, \mathrm{p}<0.001)$.
Therefore, the proposed hypothesis $\mathrm{H}_{4}$ is accepted. 
In general, all four assumed hypotheses of this study are accepted with significant level.

\section{Discussion}

Results of the study gave realistic support to the proposed theoretical model whichmeasured team performance as mediator in relation between dependent variable; transformational leadership and independent variable; project success. This statement is supported by(Mu \& Turner, 2005) where it is stated that leadership style is important factor in project success. These kind of aspects (communication, commitment and leadership) are also explained by (Alvarenga et al., 2018).Present study findings supported the literature as regression values predict the strongly positive impact of TL over project success. Previous literature focused on leadership style of leader increase project success (Ahmed, 2017) However, this study helped to extend the literature by clarifying that team's performance in projects has also significant affect on success of a project.(Liu $\&$ Wang, 2019) also explained activities needed to increase team performance which supported the results of this study that TL affect the performance of the team. Therefore, role of leader (Maqbool et al., 2017) and presence of team effectiveness(Ehrhardt et al., 2020) are necessary in any project.

\subsection{Theoretical \& Practical Implications}

This study contributes to the literature in the area of leadership and project success. This study also addresses affect of the mediating factor team performance. The results uncover that this study can be executedin practicedue of significant findings. According to our study, transformational leadership helps subordinates as well as provides advantage to organization in achieving project success. Transformational leadership is very important to achieve higher project quality, achieving project group's mission and encouraging subordinates(Keller, 2017). Thus, quality of work by subordinates facilitates to establish better team performance and increase the chances of success of project (Lindsjørn et al.,
2016). Hence, this indicates affect of transformational leadership on project success stronger when team gets more influenced by the transformational behavior of leader.

Results of present study suggest that providing more training to project leaders improve the overall performance of team and project. These suggestions help leaders to maximize benefits by attaining better results in limited resources. Thus, study showed a significant implication which is based on practical evidence and observed arguments.

\subsection{Limitations and Future Directions}

Results of this study are supportive and helpful. However, there are few limitations which needed to overcome in future research. This study was proposed to investigate the role of transformational leadership impact on project success which was limited from general to construction companies. Hence, the results werepresented specifically to the employees of private sector construction companies. We used cross-sectional designdue to limited time horizon. Future research can be done on public sector of for more specific results. In addition, this study limited by a comparatively small sample size due to time horizon and limited to only construction industry. Recommendation for future researchers on that topic is that instead of conducting a crosssectional research;conduct a longitudinal research that might providemore general results.

\section{Conclusion}

The objectives of this study include analysing transformational leadership affecton project success. This study concluded that the project success is greatly affected by transformational leadership. The results indicate that transformational leadership affect on project success is significant through the mediation of team performance. Therefore, it is useful for project leader to engage teamto enhance team performance.Future research opportunities exist to consider the effect of moderating factors, such as 
firm size and project size. In addition, future research could be assumed to examine the qualitative analysis of transformation leadership on project success.

\section{References:}

[1] Aga, D. A., Noorderhaven, N., \& Vallejo, B. (2016). ScienceDirect Transformational leadership and project success: The mediating role of team-building. JPMA, 34(5), 806-818. https://doi.org/10.1016/j.ijproman.2016.02 .012

[2] Ahmed, S. (2017). Leadership and project success in development sector. 30(4). https://doi.org/10.22367/jem.2017.30.01

[3] Alvarenga, J. C., Branco, R. R., Luis, A., Guedes, A., Alberto, C., \& Soares, P. (2018). The project manager core competencies to project success. https://doi.org/10.1108/IJMPB-12-20180274

[4] Anantatmula, V. S. (2010). Project Manager Leadership Role in Improving Project Performance. 22(1).

[5] Barrick, M. R., Stewart, G. L., Neubert, M. J., \& Mount, M. K. (1998). Relating Member Ability and Personality to WorkTeam Processes and Team Effectiveness. 83(3), 377-391.

[6] Braun, S., Peus, C., Weisweiler, S., \& Frey, D. (2013). Transformational leadership , job satisfaction, and team performance: A multilevel mediation model of trust is. The Leadership Quarterly, 24(1), 270-283. https://doi.org/10.1016/j.leaqua.2012.11.0 06

[7] Carless, S. A., Wearing, A. J., \& Mann, L. (2000). A short measure of transformational leadership. Journal of Business and Psychology, 14(3), 389-405. https://doi.org/10.1023/A:1022991115523

[8] Chen, C. C. (2016). Integrating Knowledge Activities for Team
Innovation: Effects of Transformational Leadership. $\quad \mathrm{XX}(71432005), \quad 1-29$. https://doi.org/10.1177/014920631662864 1

[9] Cheruvelil, K. S., Soranno, P. A., Weathers, K. C., Hanson, P. C., Goring, S. J., Filstrup, C. T., \& Read, E. K. (2014). Creating and maintaining high-performing collaborative research teams: the importance of diversity and interpersonal skills. https://doi.org/10.1890/130001

[10] Choi, S. B., Kim, K., Kang, S., \& City, S. (2017). EFFECTS OF TRANSFORMATIONAL AND SHARED LEADERSHIP STYLES ON EMPLOYEES , PERCEPTION OF TEAM EFFECTIVENESS. 45(3), 377386.

[11] Cleveland, S., \& Cleveland, M. (2020). Leadership Competencies for Sustained Project Success. (January). https://doi.org/10.4018/IJAMTR.2020010 103

[12] Colquitt, J. A., Scott, B. A., \&LePine, J. A. (2007). Trust, Trustworthiness, and Trust Propensity: A Meta-Analytic Test of Their Unique Relationships With Risk Taking and Job Performance. Journal of Applied Psychology, 92(4), 909-927. https://doi.org/10.1037/00219010.92.4.909

[13] Damayanti, R. W., Program, E. S., Engineering, I., Program, S., Faculty, E., Maret, S., ... Faculty, P. (2019). A MetaAnalysis Study of Leadership and Project Success. 2(IcoIESE 2018), 369-374.

[14] Davis, K. (2014). ScienceDirect Different stakeholder groups and their perceptions of project success. JPMA, 32(2), 189-201. https://doi.org/10.1016/j.ijproman.2013.02 .006

[15] Dechurch, L. A., \& Haas, C. D. (2015). Through an Episodic Lens. 542-568.

[16] Dionne, S. D., Yammarino, F. J., Atwater, L. E., Spangler, W. D., Dionne, S. D., \&Yammarino, F. J. (2015). 1163 
Transformational leadership and team performance.

https://doi.org/10.1108/095348104105306 01

[17] Ehrhardt, K., Miller, J. S., Freeman, S. J., Hom, P. W., Ehrhardt, K., Miller, J. S., ... Horn, P. W. (2020). Examining Project Commitment in Cross-Functional Teams : Antecedents and Relationship with Team Performance Examining Project Commitment in Cross-Functional Teams : Antecedents and Relationship with Team Performance. 29(3), 443-461. https://doi.org/10.1007/s

[18] Hair, J. F., Sarstedt, M., Pieper, T. M., \&Ringle, C. M. (2012). The Use of Partial Least Squares Structural Equation Modeling in Strategic Management Research : A Review of Past Practices and Recommendations for Future Applications. Long Range Planning, 45(56), $320-340$. https://doi.org/10.1016/j.lrp.2012.09.008

[19] Hair Jr., J.F., Black, W.C., Babin, B.J. and Anderson, R. E. (2010). Multivariate Data Analysis: A Global Perspective.

[20] Hoegl, M. (2006). Team goal commitment in innovative projects. 10(3), 299-324.

[21] Keller, R. T. (2017). ' Transformational ' Leaders Make a Difference. 6308(December).

https://doi.org/10.1080/08956308.1995.11 674267

[22] Krancher, O. (2018). How Social MediaEnabled Communication Awareness Enhances Project Team Performance How Social Media-Enabled Communication Awareness En- hances Project Team Performance. 19(9).

[23] Lindsjørn, Y., Sjøberg, D. I. K., Dingsøyr, T., Bergersen, G. R., \&Dyb, T. (2016). Survey of Agile Development Teams PT US

CR. https://doi.org/10.1016/j.jss.2016.09.028

[24] Lisak, A., Erez, M., Sui, Y., Lee, C., Lisak, A., \&Erez, M. (2020). The positive role of global leaders in enhancing multicultural team innovation The positive role of global leaders in enhancing multicultural team innovation. 47(6), 655673.

[25] Liu, M., \& Wang, M. (2019). A multilevel model of commitment-based human resource practices on team performance: the team cognition model. (151). https://doi.org/10.1111/1744-7941.12220

[26] Maqbool, R., Sudong, Y., Manzoor, N., \& Rashid, Y. (2017). Transformational Leadership on Project Success: An Empirical Perspective. (July), 58-75. https://doi.org/10.1177/875697281704800 304

[27] Michael, T. (2008). Project Portfolio Control and Portfolio. Project Management Journal, 39(March), 28-42. https://doi.org/10.1002/pmj

[28] Mishra, P., Pandey, C. M., \& Singh, U. (2019). Descriptive Statistics and Normality Tests for Statistical Data. 6772. https://doi.org/10.4103/aca.ACA

[29] Mu, R. (2014). Critical success factors in projects.

https://doi.org/10.1108/175383712112690 40

[30] Mu, R., \& Turner, J. R. (2005). PROJECT The impact of principal - agent relationship and contract type on communication between project owner and manager. 23, 398-403. https://doi.org/10.1016/j.ijproman.2005.03 .001

[31] Müller, R., Turner, J. R., Mu, R., \& Turner, J. R. (2012). Attitudes and leadership competences for project success.

https://doi.org/10.1108/174652610110797 30

[32] Ng, T. W. H. (2017). Transformational leadership and performance outcomes: Analyses of multiple mediation pathways. Leadership Quarterly, 28(3), 385-417. 
https://doi.org/10.1016/j.leaqua.2016.11.0

08

[33] Oke, A. E., Olatunji, S. O., Awodele, A. O., \& Akinola, J. A. (2016). I MPORTANCE OF T EAM R OLES C OMPOSITION. 8(2), 2016.

[34] Packendorff, M. L. and J. (2009). Project leadership revisited: towards distributed leadership perspectives in project research. 1(3), 285-308.

[35] Podgórska, M., \&Pichlak, M. (2019). Analysis of project managers ' leadership competencies Project success relation: what are the. https://doi.org/10.1108/IJMPB-08-20180149

[36] Prewett, M. S., Goswami, A., \& Christiansen, N. D. (2016). Effects of Team Personality Composition on Member Performance: A Multilevel Perspective. (November 2017). https://doi.org/10.1177/105960111666863 3

[37] Radujkovi, M., \&Sjekavica, M. (2017). MladenRadujkovi ć. 196(June), 607-615. https://doi.org/10.1016/j.proeng.2017.08.0 48

[38] Rebelo, T., Dimas, I. D., Lourenço, P. R., Palácio, Â., \&Rebelo, T. (2018). Generating team PsyCap through transformational leadership A route to team learning and performance. https://doi.org/10.1108/TPM-09-20170056

[39] Sebestyen, Z. (2017). Further Considerations in Project Success. Procedia Engineering, 196(June), 571577.

https://doi.org/10.1016/j.proeng.2017.08.0 32

[40] Sergey, B., \& Boris, K. (2020). Modeling of Empathy , Emotional Intelligence and Transformational Leadership to the Project Success. https://doi.org/10.1007/978-3030-25741-5
[41] Sun, W., Xu, A., \& Shang, Y. (2014). Transformational leadership, team climate , and team performance within the NPD team: Evidence from China. (28), 127147. https://doi.org/10.1007/s10490-0129327-3

[42] Sundqvist, E. (2019). The Role of Project Managers as Improvement Agents in Project-Based Organizations. 50(3), 1-15. https://doi.org/10.1177/875697281983278 4

[43] Sweis, R. J., Al Sharef, R., Jandali, D., Obeidat, B. Y., \&Andrawes, N. (2018). The relationship between project team members' effectiveness and acknowledgment of talent: Team members' perspective. International Journal of Construction Education and Research, 14(2), 141-160. https://doi.org/10.1080/15578771.2017.13 56401

[44] Troth, A. C., Jordan, P. J., Lawrence, S. A., \&Tse, H. M. (2020). A multilevel model of emotional skills, communication performance, and task performance in teams. 33(5), 700-722. https://doi.org/10.1002/job.785

[45] Turner, R. (2005). T HE P ROJECT M ANAGER' $S$ L EADERSHIP S TYLE AS A $S$ UCCESS $F$ ACTOR ON $P$ ROJECTS : A L ITERATURE R EVIEW. (January).

[46] Wang, G., Oh, I., Courtright, S. H., \& Colbert, A. E. (2011). Group \& Organization Management. https://doi.org/10.1177/105960111140101 7

[47] Wang, X. (2006). PROJECT The relationships between key stakeholders Õ project performance and project success : Perceptions of Chinese construction supervising engineers. 24, 253-260. https://doi.org/10.1016/j.ijproman.2005.11 .006

[48] Westerveld, E. (2003). The Project Excellence Model 1: linking success 
criteria and critical success factors. 21, 411-418. https://doi.org/10.1016/S02637863(02)00112-6

[49] Woerkom, M. Van. (2007). The relationships between team learning activities and team performance. https://doi.org/10.1108/004834809109780 54

[50] Wu, G., Liu, C., Zhao, X., \&Zuo, J. (2017). Investigating the relationship between communication-conflict interaction and project success among construction project teams. International Journal of Project Management, 35(8), 1466-1482.

https://doi.org/10.1016/j.ijproman.2017.08 .006

[51] Yang, L., Huang, C., \& Wu, K. (2011). The association among project manager' $\mathrm{s}$ leadership style, teamwork and project success. JPMA, 29(3), 258-267. https://doi.org/10.1016/j.ijproman.2010.03 .006

[52] Zaccaro, S. J., Rittman, A. L., \& Marks, M. A. (2001). Team leadership. 12, 451483.

[53] Zuo, J. (2018). Soft skills of construction project management professionals and project success factors A structural equation model. 25(3), 425-442. https://doi.org/10.1108/ECAM-01-20160016 